\title{
Remembering Buzz Holling
}

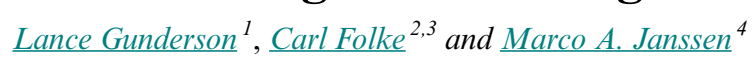

\section{INTRODUCTION}

No one knows where it will lead us, but our approach is designed to facilitate learning and to encourage productive experimentation, while retaining the traditions of sound science.

Holling, C. S. 1997.

The inaugural issue of Conservation Ecology. http://www.consecol.org/voll/iss1/art1/

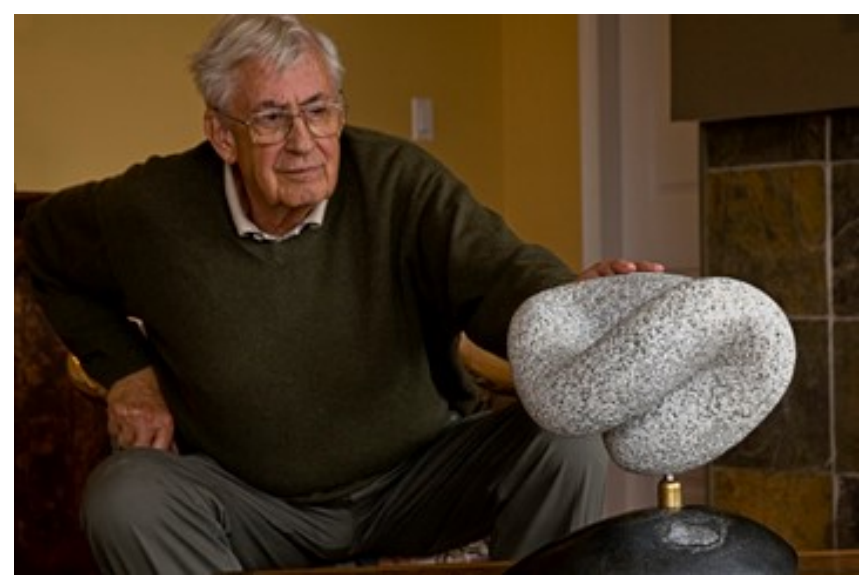

C.S. "Buzz" Holling, the founding Editor-in-Chief, passed away on 16 August 16 2019. Buzz was not only the Editor-in-Chief for the first five years, but nurtured it through an infancy of great uncertainty as to survival. As we close the 24th issue of Ecology and Society, we take time to reflect on his life and contributions, especially to the journal. He lived a remarkable life of creativity, discovery, scholarship, and service to humanity. He was a rare combination of artist, scientist, teacher, and practitioner who touched and inspired many colleagues. Because the journal Ecology and Society would not be here without Buzz, we hope to honor and memorialize his passing with a short tribute to his life and his many contributions.

One of his talents was an ability to bring people together to understand, assess, and act on new solutions to complex problems of people and nature. Indeed, the Resilience Alliance (RA) was one of his "experiments," set up as a flexible, nimble institution that would bring scientists, academics, and practitioners together as a crucible for creating novel solutions that would contribute to sustainable futures for people and the planet. The Alliance is now the publisher of the journal. At the end of this editorial, we provide a link where readers can contribute to Buzz's legacy through the RA.
One of Buzz's legacies is his adaptive cycle. The image above shows Buzz touching a sculpture by his friend and colleague Lee Gass. The piece is a three-dimensional depiction of Buzz's adaptive cycle. The RA logo is a stylized depiction of the same heuristic or mental model, which was derived from integrating and simplifying decades of ecosystem research. While appearing as an infinity or continuous loop, these representations stylize the abstract concepts of phases, discontinuities, nonlinearities imbedded in the model. At the heart of the model is an overly simplified representation of systems (ecological, biological, social, and biophysical) that change in different ways. In the model, change occurs as systems go through distinct periods or phases. First is growth and development of structure, capital, and ideas. Over time the system becomes senescent and vulnerable to external influences, resulting in periods of destructive creation followed quickly by renewal into a renewed or different system. Buzz's life was indeed a series of adaptive cycles, as indicated by his memoir (Holling 2017), as is the history of this publication.

\section{REMEMBERING BUZZ}

Crawford Stanley (Buzz) Holling was born on 6 December 1930, in Elmira, New York. He spent his formative years in Toronto and Ontario, where he collected bugs, watched birds, and honed his naturalist's skills. His preferred name of Buzz was given to him by his older sister (short form of Buzzer) and it stuck through his life. He insisted on being called Buzz throughout his life, much to the chagrin of many students and colleagues. He earned a BA and MSc at the University of Toronto in 1952 . He traveled west and earned a PhD at the University of British Columbia in 1957. He began his career as a forest entomologist in the Canadian Department of Forestry in Ontario, where he built upon his $\mathrm{PhD}$ work on predator-prey interactions. Buzz was Professor and Director of the Institute of Animal Resource Ecology at UBC. He was the Director of the International Institute for Applied Systems Analysis in Vienna, Austria, before assuming a position as an Eminent Scholar, holding the Arthur R. Marshall Jr. Chair in Ecological Sciences in the Department of Zoology at the University of Florida. He retired from the University of Florida in 2000 but remained active as an Emeritus Scholar.

Buzz received many national and international awards over his professional career. He was elected as a Fellow of the Royal Society of Canada in Animal Biology in 1970. He received two honorary Doctor of Science degrees; one from the University of Guelph (1998), and another from UBC (2007). He was a foreign member of the Royal Swedish Academy of Sciences and was also awarded the Austrian Cross of Honour for Arts and Science. The Ecological Society of America bestowed the Mercer Award in 1966 and an Eminent Ecologist Award in 1999. In 2008 he received 
the Volvo Environmental Prize. In 2009, he was awarded the Order of Canada for his work in ecology.

He embraced the uncertainty of the future, as indicated by his recognition of inherent complexity and unpredictability of the future, now manifest in the manifold resilience programs and the adoption of adaptive management throughout the world. Over the arc of his life, his leadership, friendship, support, and ideas were gifts to those of us who were lucky enough to work with him. He possessed deep insights, a visionary mind and heart, and a never ending curiosity, always emphasizing systemic understanding rather than detailed knowledge. As we are now in the second or third generation of resilience scientists and practitioners, this provides a ray of hope that his intellectual legacy will survive for years to come.

In memory of Buzz Holling, the Resilience Alliance has established a fund to carry on the legacy of interdisciplinary, integrated research carried on by the next generation of resilience scholars. The group is called the Resilience Alliance Young Scholars (RAYS). This group comprises undergraduate, graduate students, and postdoctoral researchers. Donations to the fund can be made online, https://www.resalliance.org/index.php/hollingfund. All donations to the fund will be used exclusively to support the participation of young promising scholars in research network activities by the RAYS.

\section{TRANSITIONS AT THE JOURNAL}

The journal began as Conservation Ecology, in order to publish work on the theory and application of conserving ecosystems. The initial goal was to publish high quality, peer-reviewed scientific articles on the internet. Buzz, as indicated above, saw the journal as an experiment. One of Buzz's many rules for life was the need for experimentation in times of great uncertainty. Now, more than ever, our world needs high quality, novel scholarship to help learn our way into the future. We hope that this journal will carry on Buzz's legacy and contribute to that guidance.

Another set of transitions involves new leadership in the Editorial Team. Carl Folke has decided to step away as EIC, but will continue to manage manuscripts that are still in the publication pipeline. There is not enough thanks and gratitude available to adequately acknowledge Carl's contributions to the journal over the past 17 years. Carl was the one who saw the need for a truly interdisciplinary journal that published novel and integrative work to help understand and act on the linkages between humanity and our life-supporting ecosystems. As a result of Carl's leadership, the journal now has an impact factor of 4.14 and is in the top $15 \%$ of environmental studies journals and $18 \%$ of environmental science journals. He will continue on the Board of Editors.

In the summer of 2019, the Board of Directors of the Resilience Alliance appointed Prof. Marco Janssen as Coeditor-in-Chief. Marco is a Professor in the School of Sustainability and Director of the Center for Behavior, Institutions and the Environment at Arizona State University. Marco has been an active contributor since the first issue of the journal and associate editor of Ecology and Society since 2005.
Responses to this article can be read online at: http://www.ecologyandsociety.org/issues/responses. php/11434

\section{LITERATURE CITED}

Holling, C. S. 2017. Bubbles and spirals: the memoirs of C. S. Buzz Holling. Second edition. Available online in multiple electronic formats at: http://www.stockholmresilience.org/holling-memoirs 